\title{
KONSELING TEMAN SEBAYA UNTUK MENINGKATKAN EMPATI SISWA
}

\author{
Ni Made Rahmi Suryawati \\ nimaderahmisuryawati@gmail.com
}

\begin{abstract}
The background to the research is the necessity of empathy in daily life. Empathy is the basic skill of social interaction that can be taught, developed, and trained. To be accepted by a group of peers will make a student feel worthy and happy. Students who lack social interaction will be more prone to depression and school dropout. Hence, in general the research aims to increase students' empathy through peer counseling. More specifically, it aims to: (1) Find the profile of students' empathy treated with peer counseling; (2) Find the hypothetical formulation for student peer counseling; and (3) Find the effectiveness of peer counseling in increasing students' empathy. The SMP of UPI Laboratory School Bandung has been selected as the research location, with 175 seventh grade students as the research population. The school was selected because some of its students showed a lack of empathy, causing them to have difficulty to socialize, become distant from their friends, lack social awareness, have a desire to be more popular, and feel alienated. In fact, it was found that $40 \%$ of the students were at the low category of empathy, 45\% of them were at the medium category, and only 15\% were at the high category. This fact was ameliorated by the lack of guidance and counseling teachers. The research adopted quasi-experimental method with nonequivalent (pretest-posttest) control group design, where the experimental group and control group were not randomly selected in order to find the difference between the group given intervention and the one without intervention. Before intervention, students were trained with peer counseling. After intervention, students who had low empathy experienced an increase in their test scores, and they showed positive behavioral changes. Therefore, it can be concluded that peer counseling was effective to increase the empathy of the seventh grade students of SMP of UPI Laboratory School Bandung School Year 2014-2015.
\end{abstract}

Keywords: Peer Counseling, Group Counseling, Empathy

ABSTRAK
Penelitian ini dilatarbelakangi pentingnya memiliki sikap empati dalam kehidupan sehari-hari. Sikap empati merupakan keterampilan dasar dalam menjalin hubungan sosial yang dapat diajarkan, dikembangkan, dan dilatih. Siswa merasa berharga dan bahagia apabila dapat diterima dalam situasi kelompok oleh sebayanya. Kekurangan hubungan sosial pada siswamengakibatkan depresi hinggadrop out sekolah. Secara umum penelitian ini bertujuan untuk meningkatkan empati siswa melalui konseling teman sebaya (KTS). Secara khusus, bertujuan untuk (1) mengetahui profil empati siswa sebelum diberikan bantuan KTS, (2) mengetahui rumusan hipotetik program KTS pada siswa, dan (3) mengetahui efektivitas KTS untuk meningkatkan empati siswa. Populasi penelitian adalah siswa kelas VII dengan jumlah 175 orang yang berlokasi di SMP Laboratorium Percontohan UPI Bandung. Pemilihan lokasi penelitian disebabkan fenomena perilaku siswa yang kurang berempati dapat dilihat dari siswa susah bergaul, tidak akrab dengan teman, tidak peduli, ingin lebih populer, dan merasa tidak memiliki teman. Faktanya, terdapat $40 \%$ siswa pada kategori rendah, $45 \%$ siswa pada kategori sedang, dan hanya $15 \%$ siswa yang berada pada kategori tinggi, serta kurangnya jumlah guru bimbingan dan konseling. Metode penelitian yang digunakan adalah eksperimen-kuasi dengan nonequivalent (pretest-posttest) control group design, kelompok eksperimen dan kelompok kontrol tidak dipilih secara acak, untuk mengetahui perbedaan kelompok yang diberikan intervensi dengan kelompok yang tidak diberikan intervensi. Sebelum memberikan intervensi konselor sebaya diberikan pelatihan keterampilan KTS. Setelah intervensi, siswa yang memiliki empati rendah mendapatkan peningkatan skor dan perubahan prilaku yang positif. Sehingga, hasil temuan penelitian menunjukkan konseling teman sebaya efektif untuk meningkatkan empati siswa kelas VII SMP Laboratorium Percontohan UPI Bandung Tahun Ajaran 2014-2015.

Kata kunci: konseling teman sebaya (KTS), konseling kelompok, empati

\section{PENDAHULUAN}

Masa remaja merupakan perkembangan transisi antara masa anak menuju masa dewasa. Perkembangan yang terjadi pada masa remaja mencakup perubahan secara emosional, biologis, kognitif dan sosialemosional.Hurlock, (2000:206) menjelaskan masa remaja merupakan masa yang sarat akan konflik, karena pada masa perkembangan ini tiap individu mengalami perubahan yang sangat kompleks, yaitu perubahan fisik, pola perilaku, peran sosial, serta merupakan masa pencarian identitas untuk menjadi diri sendiri sebagai individu. Pada masa potensial 
remaja dapat berkembang kearah positif maupun negatif. Mencapai pendidikan yang edukatif, remaja membutuhkan bimbingan dan pendampingan menuju kearah perkembangan potensi remaja yang positif dan produktif. Menurut Ali, (2008: 09) masa remaja adalah masa sosial karena sepanjang masa remaja hubungan sosial semakin tampak jelas dan sangat dominan. Penghayatan kesadaran akan kesunyian yang mendalam dari remaja merupakan dorongan pergaulan untuk menemukan pernyataan diri akan kemampuan kemandiriannya.

Segmen kehidupan yang penting dalam siklus perkembangan siswa berada pada masa transisi dari masa anak ke masa dewasa, yang diarahkan pada perkembangan masa dewasa yang sehat. Menurut Yusuf, (2009 : 10) aspek-aspek perkembangan remaja antara lain: "1) aspek fisik, 2) aspek intelektual (kognitif), 3) aspek emosi, 4) aspek sosial, 5) aspek kepribadian, dan 6) kesadaran beragama". Terkait dengan aspekaspek perkembangan yang dimiliki remaja serta perubahan kehidupan yang terjadi pada masa remaja yaitu transisi dari masa anakanak menuju masa dewasa memungkinkan remaja tidak siap akan perubahan yang singkat, memungkinkan munculnya beberapa masalah yang terjadi pada remaja. Masalahmasalah remaja dikelompokkan dalam: 1) masalah pribadi, 2) masalah sosial, 3) masalah belajar, dan 4) masalah karir.

Penelitian yang dilakukan Hartup (1996, 2000, 2001: Hartup dan Abecassiss, 2002 (dalam Santrock 2004, hlm. 352) selama tiga periode menunjukkan bahwa sahabat dapat menjadi sumber-sumber kognitif dan emosi sejak masa kanak-kanak sampai dengan masa tua. Sahabat dapat memperkuat harga diri dan perasaan bahagia. Penelitian lain menemukan bahwa dukungan teman sebaya banyak membantu atau memberikan keuntungan kepada anak-anak yang memiliki permasalahan sosial dan permasalahan keluarga, dapat membantu memperbaiki iklim sekolah, serta memberikan pelatihan keterampilan sosial (Cowie dan Wellace, 2000, hlm. 8).

Menurut Hurlock, (1980 : 213) salah satu "permasalahan remaja yang tersulit adalah masalah sosial". Untuk mencapai tujuan dari pola sosialisasi dewasa, remaja harus membuat banyak penyesuaian baru. Hal terpenting dan tersulit adalah penyesuaian diri dengan meningkatnya pengaruh kelompok sebaya, perubahan dalam perilaku sosial, dalam seleksi persahabatan, nilai-nilai baru dalam dukungan dan penolakan sosial, dan nilai-nilai baru dalam seleksi pemimpin. Penyesuaian sosial didasarkan pada sikap empati yang ada dalam diri remaja. Sikap empati mampu mengajarkan individu dalam memahami alur pemikiran dan apa yang diperlukan oleh teman sebaya.

Eisenberg (2002) berpendapat bahwa ciri-ciri empati adalah "Proses individu berempati melibatkan aspek afektif dan kognitif'. Aspek afektif yang dimaksud adalah kecenderungan seseorang untuk mengalami perasaan emosional orang lain yaitu ikut merasakan ketika orang lain merasa sedih, menangis, terluka, menderita, bahkan disakiti. Sedangkan, aspek kognitif dalam empati difokuskan pada proses intelektual untuk memahami perspektif orang lain dengan tepat dan menerima padangan mereka, misalnya membayangkan perasaan orang lain ketika marah, kecewa, senang, memahami keadaan orang lain dari: cara berbicara, dari raut wajah, dan cara pandang dalam berpendapat.

Kumar(dalam Wiryanto, 2005) dan De Vito (dalam Eisenberg, 2002) menyebutkan "ciriciri dalam komunikasi antar pribadi adalah keterbukaan (openness), empati (empathy), dukungan (supportiveness), rasa positif (positiveness), dan kesetaraan atau kesamaan 
(equality)". Pada kenyataan yang terjadi di kelas VII SMP Laboratorium Percontohan UPI Bandung belum terwujud dengan sejalan antara empati dan cara komunikasi antar pribadi yang baik. McDonald dan Messinger (2014, hlm. 2) berpendapat "Empathy is a potential psychological motivator for helping others in distress. Empathy can be defined as the ability to feel or imagine another person's emotional experience. The ability to empathize is an important part of social and emotional development, affecting an individual's behavior toward others and the quality of social relationships".

Sikap empati dapat menjadi motivator psikologis pada diri individu untuk membantu orang lain dalam kesulitan. Empati dapat didefinisikan sebagai kemampuan untuk merasakan atau membayangkan pengalaman emosional orang lain. Kemampuan untuk berempati merupakan bagian penting dari perkembangan sosialdan emosional, yang mempengaruhi perilaku individu terhadap orang laindan kualitas hubungan sosial. Winkel \& Hastuti (2006) mengemukakan bahwa kebutuhan siswa pada rentang usia 16-19 tahun bersifat psikologis, seperti mendapat perhatian dan dukungan tanpa pamrih, mendapat pengakuan terhadap keunikan alam pikiran dan perasaannya, menerima kebebasan yang wajar dalam mengatur kehidupannya sendiri tanpa dilepaskan dari perlindungan keluarga, memperoleh prestasi yang patut dibanggakan dalam bidang akademik dan nonakademik, membina persahabatan dengan teman sejenis dan lawan jenis, memiliki cita-cita yang pantas untuk dikejar.

Namun, jika salah satu dari keinginan siswa tidak terpenuhi secara berlarut-larut, khususnya pada kebutuhan dalam hubungan sosial maka akan menimbulkan konflik batin dan kondisi yang terasa asing di lingkungan sekolah. Melihat kenyataan yang terjadi pada siswa kelas VII SMP Laboratorium Percontohan UPI Bandung, dalam studi pendahuluan penulis mengamati terdapat siswa yang menunjukkan sikap egois, hanya ingin didengar, tidak peduli dengan teman, dan ingin menang sendiri yang membuat teman-temannya menjauhinya hingga merasa dapat melakukan semua hal sendiri. Setelah dilakukan pengamatan yang lebih mendalam, dapat diketahui bahwa siswa tersebut memiliki sikap empati yang rendah. Faktanya, dari hasil sosiometri menujukkan terdapat rata-rata 5 orang siswa yang paling banyak tidak disukai dimasingmasing kelas VII. Sedangkan, dari hasil ATP menunjukkan bahwa kurangnya komunikasi antar pribadi, kurangnya sikap ramah dan menghargai teman pada siswa, serta siswa terlihat acuh dengan lingkungan kelasnya. Walaupun secara umum, siswa nampak sudah memahami makna empati, namun siswa belum menerapkan sepenuhnya aspekaspek empati dalam kehidupan sehari-hari khususnya di sekolah. Sehingga, secara umum penelitian ini bertujuan untuk mengetahui efektivitas konseling teman sebaya dalam meningkatkan empati pada siswa di sekolah.

\section{KAJIAN PUSTAKA \\ Konsep Empati}

Membangun dan menumbuhkan sikap empati dalam diri, diperlukan hubungan yang baik dengan masyarakat maupun teman sebaya. Sikap empati dapat mengajarkan tentang cara memahami lingkungan, kondisi teman sebaya, dan dapat membantu teman sebaya yang sedang mengalami permasalahan. McDonald \& Messinger, (2014: 2) berpendapat sikap empati dapat menjadi motivator psikologis pada diri individu untuk membantu orang lain dalam kesulitan. Empati dapat didefinisikan sebagai kemampuan untuk merasakan atau membayangkan pengalaman emosional orang lain. Kemampuan untuk 
berempati merupakan bagian penting dari perkembangan sosial dan emosional, yang mempengaruhi perilaku individu terhadap orang lain dan kualitas hubungan sosial.

Kebutuhan remaja untuk diterima dan disukai dalam hubungan sosial atau kelompok sebaya yang luas, dapat menimbulkan perasaan senang, namun timbul rasa cemas, stres, dan diisolir ketika remaja tidak diterima oleh teman sebaya di lingkungannya. Menurut Santrock, (2007 : 311), sebagian besar remaja merasa dilihat oleh sebayanya adalah aspek yang paling penting dalam kehidupan mereka, dan satu fungsi teman sebaya adalah sebagai satu sumber informasi tentang dunia diluar keluarga. Sehingga remaja, dalam hal ini siswa perlu memiliki kemampuan untuk memahami perasaan dan memikirkan sesuatu yang terjadi pada orang lain yang merupakan wujud dari sikap empati.

Istilah "empati" berasal dari kata Einfuhlung yang digunakan oleh seorang psikolog Jerman, yang berarti "merasa terlibat" (Tubbs, 2000 : 2). Kata empati dalam bahasa Inggris (empathy) ditemukan pada tahun 1909 oleh Titchener (Wikipedia, 2014). Selanjutnya, Eisenberg, (2002 : 9) menyatakan empati adalah sebuah respon afektif yang berasal dari penangkapan atau pemahaman keadaan emosi atau kondisi lain, dan kemudian menyesuaikan pandangan afektifnya dengan perasaan atau kondisi orang tersebut. Hoffman, (2000 : 4) menyatakan empati adalah "an affective response more appropriate to another's situation than one's own". Empati juga berarti kemampuan yang dimiliki seseorang untuk dapat merasakan posisi orang lain dan dapat mengahayati pengalaman dari orang lain tersebut. Seseorang yang mampu merasakan atau memahami keadaan emosi orang lain merupakan bentuk dari empati yang tetap menjaga realitas dirinya. Emosi yang menggugah bukan berarti akan membuat seseorang menjadi kehilangan identitas dan realitas dirinya.

Empati merupakan bagian penting dari kompetensi sosial, karena empati merupakan unsur-unsur dari kecerdasan sosial competency. Komponen-komponen yang berhubungan erat dengan kompetensi sosial meliputi: empati dasar, penyelarasan, ketepatan empati, dan pegertian sosial. Empati menjadi dasar individu dalam memahami perasaan orang lain atau merasakan isyaratisyarat emosi nonverbal. Penyelarasan dalam mendengarkan dengan penuh reseptivitas (penerimaan dan keterbukaan terhadap saran), dan menyelaraskan diri pada seseorang. Sikap empati dalam memahami pikiran, perasaan serta maksud orang lain dan pengertian sosial untuk mengetahui bagaimana menciptakan hubungan sosial. Goleman, (2007 : 114) mengungkapkan hal serupa mengenai empati yang merupakan proses penting, tidak hanya dalam membentuk karakter tetapi juga dalam membaca permainan-permainan atau pengalaman-pengalaman orang lain.

Menurut Eisenberg (2002) dalam empati terdapat aspek afektif dan aspek kognitif yang dijelaskan sebagai berikut: (a) Aspek afektif, merupakan kecenderungan seseorang untuk mengalami perasaan emosional orang lain yaitu ikut merasakan yang orang lain rasakan, misalnya: ketika orang lain merasa sedih, terluka, menderita atau disakiti. (b) Aspek kognitif, dalam empati difokuskan pada proses intelektual untuk memahami perspektif atau sudut pandang orang lain dengan tepat dan menerima pandangan mereka, misalnya membayangkan perasaan orang lain ketika marah, kecewa, senang, memahami keadaan orang lain dari cara bicara, dari raut wajah, cara pandang dalam berpendapat.

\section{Konsep Konseling Teman Sebaya}

Menurut Hurlock, (1980 : 213) salah satu 
"permasalahan remaja yang tersulit adalah masalah sosial". Untuk mencapai tujuan dari pola sosialisasi dewasa, remaja harus membuat banyak penyesuaian baru. Hal terpenting dan tersulit adalah penyesuaian diri dengan meningkatnya pengaruh kelompok sebaya, perubahan dalam perilaku sosial, dalam seleksi persahabatan, nilai-nilai baru dalam dukungan dan penolakan sosial, dan nilai-nilai baru dalam seleksi pemimpin. Penyesuaian sosial didasarkan pada sikap empati yang ada dalam diri remaja. Sikap empati mampu mengajarkan individu dalam memahami alur pemikiran dan apa yang diperlukan oleh teman sebaya.

Pada dasarnya hubungan sosial didasari atas keberadaan dan penerimaan oleh teman sebaya atau sahabat. Ketika siswa diterima dalam situasi kelompok oleh sebayanya, maka siswa merasa berharga dan bahagia. Yusuf \& Juntika (2011: 33) "siswa yang diterima oleh teman-temannya, dia akan mengembangkan sikap positif terhadap dirinya, dan juga orang lain. Dia merasa menjadi orang yang berharga". Kebahagiaan yang dirasakan siswa secara langsung dapat meningkatkan harga diri dan merasa termotivasi oleh keberadaan teman sebayanya. Sehingga, diperlukan kepekaan, kepedulian, dan sikap empati dalam diri siswa untuk mempertahankan keharmonisan hubungan dengan teman sebaya.

Tindall \& Gray, (1985:5) mengemukakan "Peer Counselingis defined as variety of interpersonal helping behaviours assumed by nonprofessionals who undertake a helping role with others". Lebih lanjut dijelaskan bahwa: "Peer Counseling includes one-toone helping relationships group leadership, discussion leadership, advisement, tutoring, and all activities of an interpersonal human helping or assisting nature". Konseling teman sebaya merupakan salah satu variasi dari layanan konseling dalam membantu perubahan tingkah laku baik individu maupun kelompok oleh teman sebaya (nonprofesional).

Dalam teori Piaget, (1932) dan teori Sullivan, (1953) menekankan bahwa melalui interaksi sosial anak dan remaja belajar hubungan timbal balik yang simetris. Anak-anak mengeskplorasi prinsipprinsip kejujuran dan keadilan melalui ketidaksetujuan dengan sebaya. Anak juga belajar menjadi pengamat yang teliti dari minat-minat sebayanya dan perspektifnya dalam keterpaduannya dalam berbagai aktivitas sebaya. Remaja belajar menjadi terampil dan sensitif terhadap partner dalam hubungan yang intim oleh tempaan persahabatan tertutup dengan sebaya yang dia pilih (Santrock, 2007 : 312).

Pengaruh negatif pada anak dan remaja menimbulkan perasaan ditolak dan dipandang rendah oleh sebaya yang membuat munculnya permusuhan atau rasa kesepian. Menurut penelitian yang dilakukan oleh Willard Hartop, 1996, 2000, 2001; Hartup dan Abecassiss, 2002 (Santrock, 2004: 352) selama tiga dekade yang dikemukakan Suwarjo, 2008 adalah sahabat dapat menjadi sumber-sumber kognitif dan emosi sejak masa kanak-kanak hingga denga masa tua. Dukungan teman sebaya membantu atau memberikan dukungan kepada anakanak yang memiliki masalah sosial, dapat memperbaiki iklim sekolah, serta memberikan pelatihan keterampilan.

Fattah, (2012: 91) mengungkapkan bahwa "keberadaan kelompok adalah terdapatnya orang-orang yang mengakui keberadaan suatu hubungan sosial sebagai suatu kelompok atau mereka memiliki kesadaran bahwa mereka merupakan satu kesatuan. Kesadaran mencakup rasa simpati dan empati kepada sesama anggota kelompok yang sama". Tindall \&Gray, (1985: 5) mengemukakan "peer counseling akan 
berjalan sukses dengan dukungan kelompok jika dilatih dengan pantas".

Adapun tahapan pelatihan keterampilan dasar konseling yang diberikan pada konselor sebaya yang meliputi: (1) attending, yaitu melatih konselor teman sebaya dalam memahami keterampilan komunikasi verbal dan nonverbal dalam melayani konseli, (2) empathizing, yaitu keterampilan dalam memahami prasaan dan keadaan orang lain, (3) summarizing, yaitu keterampilan dalam menyimpulkan pernyataan konseli yang kemudian dapat menjadi satu pernyataan yang mewakili pernyataan konseli dan mengandung solusi, (4) questioning, yaitu keterampilan dalam mengemukakan pertanyaan efektif untuk memperoleh informasi secara mendalam dari konseli, (5) genuiness, yaitu keterampilan mengkomunikasikan dan penerimaan perasaan secara jujur sehingga terjalin hubungan yang baik antara konselor dengan konseli, (6) assertiveness, yaitu keterampilan dalam mengekspresikan ketegasan pemikiran dan perasaan mengenai konseli tanpa menyakiti hati konseli, (7) confrontation, yaitu keterampilan komunikasi yang dapat menentang pemikiran dan perasaan konseli, dan (8) problem solving, yaitu keterampilan dalam mengeksplorasikan suatu masalah, memahami penyabab terjadinya masalah tersebut, dan mengevaluasi tindakan yang mempengaruhi pemecahan masalah.

\section{METODE}

Penelitian mengenai konseling teman sebaya untuk meningkatkan empati siswa dilakukan dalam pembelajaran sehari-hari, sehingga tidak memungkinkan mengontrol variabel lain selain variabel konseling teman sebaya dan variabel empati secara ketat. Maka metode penelitian yang digunakan adalah eksperimen kuasi (quasi experiment) dengan nonequivalent (pretest-posttest) control group design, serta kelompok eksperimen dan kelompok kontrol tidak dipilih secara random.Teknik ini digunakan untuk mengetahui kelompok yang diberikan intervensi dengan kelompok yang tidak diberikan intervensi (Creswell, 2008 : 313).

Teknik pengambilan sampel menggunakan teknik nonprobability sampling yaitu teknik mengambilan sampel yang tidak memberikan peluang/kesempatan bagi setiap unsur atau anggota populasi untuk dipilih menjadi sampel. Penentuan sampel yang diteliti, berdasarkan data hasil pengukuran tingkat empati pada populasi. Sampel yang dipilih untuk menjadi kelompok penelitian dalam kelompok eksperimen dan kelompok kontrol adalah siswa yang memiliki tingkat kemampuan empati rendah yang berjumlah 15 siswa. Penentuan jumlah penelitian mengacu pada kebutuhan di lapangan dan sesuai dengan pendapat Creswell, (2008 : 156) yaitu, "Dalam penelitian eksperimen, estimasi jumlah sampel yang dibutuhkan untuk prosedur pengolahan statistik sehingga dapat mewakili populasi secara tepat adalah sekitar 15 orang".

Siswa dengan tingkat empati rendah yang dijadikan sebagai sampel penelitian sebanyak 15 orang. Dari 15 orang siswa yang memiliki empati rendah, memiliki kelemahan pada aspek-aspek berikut: (1) kurang dapat memahami dan peduli terhadap perasaan orang lain, (2) kurang dapat mengkomunikasikan perasaan secara verbal maupun nonverbal, (3) kurang dapat memahami keadaan orang lain dari sudut pandang orang lain, dan (4) belum dapat memberikan saran pada teman yang memiliki masalah.

\section{HASIL DAN PEMBAHASAN}

Pembahasan hasil penelitian diawali dengan analisis profil empati siswa kelas VII SMP Laboratorium Percontohan UPI 
BandungTahun Ajaran 2014-2015. Siswa kelas VII berjumlah 175 orang yang tersebar di enam kelas yaitu, kelas VII A, VII B, VII C, VII D, VII E, dan VII F. Analisis profil siswa dilakukan dengan menggunakan kuesioner, untuk mendeskripsikan data empiris mengenai kemampuan empati siswa sebelum dan setelah diberikan bantuan konseling teman sebaya. Serta efektivitas program konseling teman sebaya untuk meningkatkan empati siswa kelas VII SMP Laboratorium Percontohan UPI Bandung. Eksperimen berupa pelaksanaan bantuan konseling teman sebaya diujicobakan guna memperoleh gambaran efektivitas konseling teman sebaya untuk meningkatkan empati siswa kelas VII SMP Laboratorium Percontohan UPI Bandung.

Hasil studi pendahuluan menunjukkan bahwa dari 175 siswa kelas VII di SMP Laboratorium Percontohan UPI Bandung, terdapat $40 \%$ siswa yang berada pada kategori rendah, 45\% siswa berada pada kategori sedang, dan hanya $15 \%$ siswa yang berada pada kategori tinggi. Perolehan data tersebut menunjukkan rendahnya tingkat empati pada siswa kelas VII SMP Laboratorium Percontohan UPI Bandung. Secara visual dapat digambarkan pada tabel Gambaran Umum Tingkat Empati Siswa Kelas VII SMP Laboratorium Percontohan UPI Bandung Tahun Ajaran 2014-2015 berikut.

\begin{tabular}{ccccc}
\hline \multirow{2}{*}{ Kelas } & \multirow{2}{*}{ Jumlah Siswa } & \multicolumn{3}{c}{ Kategori Kemampuan Empati } \\
\cline { 2 - 5 } & & Tinggi & Sedang & Rendah \\
\hline VII A & 29 & 5 & 12 & 12 \\
\hline VII B & 30 & 2 & 17 & 11 \\
\hline VII C & 30 & 2 & 14 & 14 \\
\hline VII D & 30 & 10 & 8 & 12 \\
\hline VII E & 27 & 4 & 14 & 12 \\
\hline VII F & 29 & 3 & 14 & $\mathbf{7 0}$ \\
\hline Jumlah & $\mathbf{1 7 5}$ & $\mathbf{2 6}$ & $\mathbf{7 9}$ & $\mathbf{4 0 \%}$ \\
\hline Persentase & $\mathbf{1 0 0 \%}$ & $\mathbf{1 5 \%}$ & $\mathbf{4 5 \%}$ & \\
\hline
\end{tabular}

Siswa dengan tingkat empati rendah yang dijadikan sebagai sampel penelitian sebanyak 15 orang. Dari 15 orang siswa yang memiliki empati rendah, memiliki kelemahan pada aspek-aspek berikut: (1) kurang dapat memahami dan peduli terhadap perasaan orang lain, (2) kurang dapat mengkomunikasikan perasaan secara verbal maupun nonverbal, (3) kurang dapat memahami keadaan orang lain dari sudut pandang orang lain, dan (4) belum dapat memberikan saran pada teman yang memiliki masalah.

Fenomena rendahnya sikap empati siswa di SMP Laboratorium Percontohan UPI Bandung secara lebih rinci ditunjukkan dengan sikap siswa yang individualisme, kurang memahami perasaan teman, merasa bisa melakukan semua hal sendiri, kurang dapat mengkomunikasikan perasaan secara verbal maupun nonverbal, merasa tidak membutuhkan bantuan orang lain, tidak mendapat kelompok saat diskusi di kelas hingga tidak memiliki teman di kelas. Eisenberg dan Strayer (dalam Pandiangan, 2005) membuktikan bahwa empati memiliki peranan yang besar dalam menggerakkan perilaku positif kepada orang lain. Selanjutnya penelitian lain membuktikan bahwa individu yang memiliki empati yang tinggi lebih berorientasi kepada orang lain yang mengalami kesulitan dan cenderung berusaha meringankan kesulitan orang lain dengan cara membantu dan mengatasi permasalahan-permasalahan orang tersebut tanpa banyak mempertimbangkan pengorbanan waktu, tenaga, dan biaya yang harus dikeluarkan. 
Rendahnya empati siswa memungkinkan terjadinya perilaku antisosial, termasuk mengisolir diri. Siswa dengan empati rendah merasa sulit bergaul, tidak akrab dengan teman, ingin lebih populer, merasa tidak ada orang yang dapat dijadikan tempat mengeluh atau bercerita, dan acuh dengan keadaan sekitar. Artinya siswa dengan empati rendah memang mempunyai masalah dalam membina hubungan atau melakukan relasi dengan teman. Para siswa dengan empati rendah cenderung tidak disukai oleh teman yang lain, walaupun tidak dinyatakan secara terus terang. Kurangnya penerimaan oleh lingkungan sekitar menjadi dampak dari rendahnya kemampuan dalam bersosialisasi.

Empati merupakan bagian penting dari kompetensi sosial, karena empati merupakan unsur-unsur dari kecerdasan sosial competency. Komponen-komponen yang berhubungan erat dengan kompetensi sosial meliputi: empati dasar, penyelarasan, ketepatan empati, dan pegertian sosial. Empati menjadi dasar yakni memiliki perasaan dengan orang lain atau merasakan isyaratisyarat emosi nonverbal. Penyelarasan dalam mendengarkan dengan penuh reseptivitas (penerimaan dan keterbukaan terhadap saran), meyelaraskan diri pada seseorang. Ketepatan empati yakni memahami pikiran, perasaan dan maksud orang lain dan pengertian sosial yakni mengetahui bagaimana dunia sosial bekerja (dalam Goleman, 2007 : 114) empati merupakan proses yang penting, tidak hanya dalam membentuk karakter tetapi juga dalam membaca permainan-permainan. Adapun peningkatan empati siswa terlihat dalam grafik Gambaran Tingkat Empati Siswa Kelas VII SMP Laboratorium Percontohan UPI Bandung yang Menjadi Partisipan Penelitian Setelah Intervensi berikut.

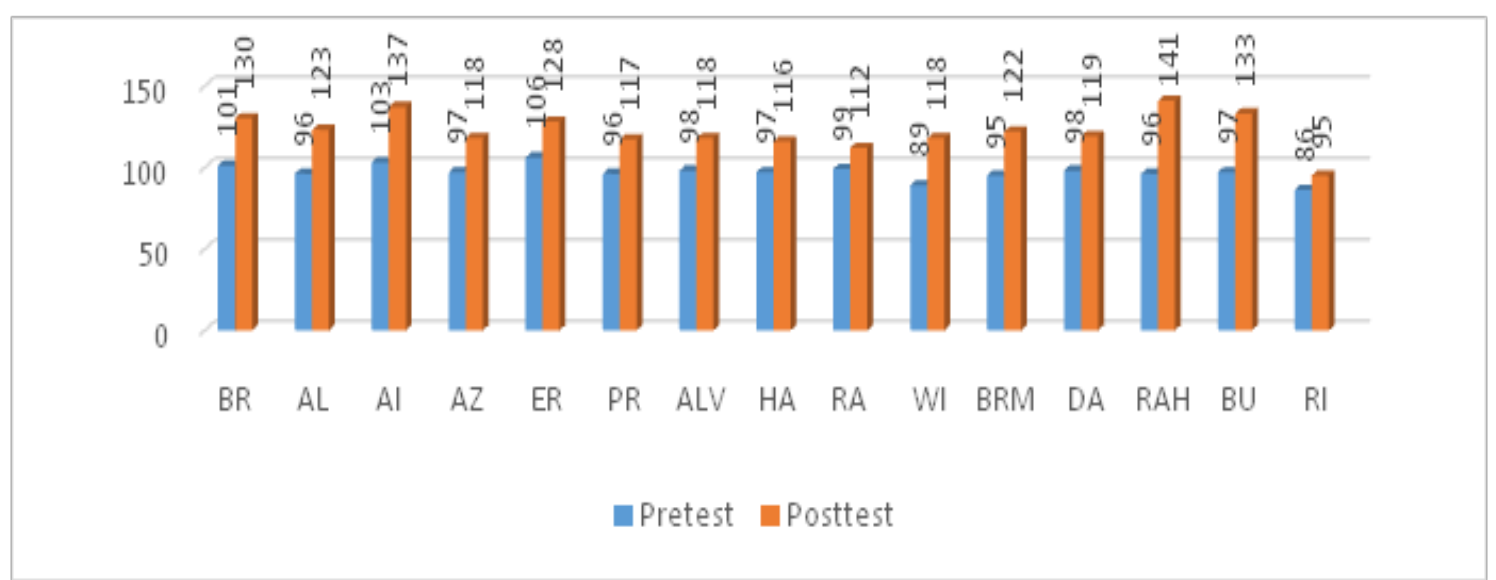

Berdasarkan hasil analisis data dan kondisi empiris di SMP Laboratorium Percontohan UPI Bandung, menunjukkan bahwa adanya peningkatan empati siswa setelah diberikan bantuan konseling teman sebaya. Peningkatan yang terjadi pada siswa menjelaskan bahwa konseling teman sebaya efektif untuk meningkatkan empati siswa. Secara keseluruhan siswa menyadari pentingnya melakukan komunikasi efektif yang dapat mempermudah dalam bersosialisasi dengan sebayanya. Disamping itu, siswa juga menyadari bahwa dalam bersosialisasi sangat penting memahami perasaan atau kondisi orang lain. Melatih kemampuan dalam komunikasi nonverbal seperti: bahasa tubuh, mimik wajah, posisi duduk, dan nada suara juga membantu konseli untuk memahami serta menerapkan aspek-aspek empati.

\section{SIMPULAN}

Hasil intervensi yang telah diberikan dapat disimpsulkan bahwa konseling teman sebaya efektif untuk meningkatkan empati siswa. Efektivitas ini dilihat dari beberapa hal diantaranya adalah dengan adanya 
peningkatan skor sikap empati berdasarkan analisis data dan perubahan sikap positif yang ditunjukkan oleh konseli. Serta, berdasarkan hasil uji Wilcoxon menunjukkan konseling teman sebaya efektif untuk meningkatkan empati konseli AI, konseli AZ, konseli RA, konseli RI, konseli BRM, konseli BR, konseli ER, konseli PR, konseli WI, konseli BU, konseli AL, konseli ALV, konseli HA, konseli DA, dan konseli RAH.

Selain itu, pedoman konseling teman sebaya dalam setting kelompok menunjukkan efektivitas yang tinggi dilihat dari peningkatan kepercayaan diri konselor sebaya saat intervensi. Konselor sebaya terlihat semakin antusias dalam membantu permasalahan yang terjadi pada konseli. Serta mampu menerapkan tahapan-tahapan dalam konseling. Sehingga tercipta keakraban diantara konselor dan konseli, keakraban yang terjalin menumbuhkan kepercayaan pada konseli dan dapat membuat konseli menjadi terbuka dengan permasalahannya.

Dengan demikian, dapat terbukti bahwa dengan konseling teman sebaya dapat meningkatkan empati siswa. Didukung dengan perencanaan program yang tepat, pemilihan konselor sebaya berdasarkan sosiometri dan wawancara guru bimbingan dan konseling di sekolah, pelatihan konseling sebaya diberikan dengan memberikan contoh-contoh kasus dan simulasi, menjalin keakraban dengan konselor sebaya, mendiskusikan setiap kegiatan dengan guru bimbingan dan konseling, melakukan evaluasi pada setiap akhir kegiatan, serta waktu intervensi yang tepat dapat membantu kelancaran terlaksananya proses konseling teman sebaya untuk meningkatkan empati siswa. Khususnya pada siswa kelas VII SMP Laboratorium Percontohan UPI Bandung Tahun Ajaran 2014-2015 yang menjadi partisipan dalam penelitian.

\section{DAFTAR RUJUKAN}

Ali. Moh \&Asrori. Moh. (2008). Psikologi remaja. Jakarta: Bumi aksara.

Almasi, J.F. (1994). The nature of fourth graders' sociocognitive conflicts in peers led and teracher-led discussions of literature. Reading Reaserch Quarterly, 29. 4. 304-306.

Aring, C. D. (1958). Sympathy and empathy. Journal of the AmericanMedical Association, 167, 448-452.

Astarini, Isna. (2013). Peningkatan empati melalui program berbasis penguatan sumberdaya psikologis. Tidak diterbitkan. Yogyakarta: Skripsi pada Fakultas Ilmu Sosial dan Humaniora Universitas Islam Negeri Sunan Kalijaga.

Atkinson, A.P, 2007. "Face processing and empathy." In T. F. D. Farrow, and P. W. R. Woodruff (eds). Empathy in Mental Illness, New York: Cambridge University Press, pp. 360-386

Auliyah, Ala. (2014). Efektivitas penggunaan media film untuk meningkatkan empati siswa. tidak diterbitkan. Malang: Skripsi pada Program Studi BK UNM

Bamberger, P., and Sonnenstuhl, W.J. (1995). Peer referal networks and utilization of a union-based EAP. The Journal of Drug Isue, Vol.25 (2), halaman 291-312

Barclay, J.H., \& Harlan, W.J. (1995). Peer performance appraisals: The impact of rate competence, rate location, rating correctability on fairness perception. Group \& Organization Management, Vol 20 (1), halaman $39-60$

Baron \& Byrne. (2004). Psikologi sosial. Jilid II (Terjemahan). Jakarta: Erlangga.

Beaty, J.J. (1998). Observing development of the young child. New Jersey: Prentice-Hall, Inc

Blatner. 2002. Relationship bettwen competitiveness and empathy in 6 and 7 years old journal of development psycology. Vol.15 No.2 Hal. 221-222

Burley, S., Gutkin, T., \& Naumann, W. (1994). Assessing the efficacy of an academic hearing peer tutor for a 
profoundly deaf student. American Annals og the Deaf. Vol 139 (4), halaman 415-419

Carr, R.A. (1981). Theory and practice of peer counseling. Ottawa: Canada Employement and Immigration Commission

Charlebois, P. Leblanc, M., Tremblay, R.E., Gagnon, C. \& Lavivee, S. (1995). Teacher, mother, and peer support in the elementary shcool as protective factors against juvenile delinquency. Intenational Journal of Behavioral Development, Vol.18 (1), hal. 1-22

Chen, X.Y., Li, Z.Y., \& Rubin, K.H. (1995). Social functioning and adjusment in chinese children.Develompment Psychology, Vol.31 (4), hal. 531-539

Colman, A. M. (2001). A dictionary of psychology. London, UK: Oxford University Press.

Cotton, K. 2001. Developing empathy in children and youth. School Impeovement Reaserch Series. Nortwest Regional Educational Laboratory.

Clark, K. B. (1980). Empathy a neglected topic in psychological research. AmericanPsychologist, 35, 187-190.

Cress, S.W., \& Holm, D.T. (2000). Developing empathy trough children's literature. education, 593-597

Creswell. (2008). Educational research: Planning, Conducting, and Evaluating Quantitative and Qualitative Research $3^{\text {rd }}$ Edition. USA: Pearson.

Davis, M.H. (1980). A Multidimensional approach to individual differences in emphaty. Florida: Catalog of Selected Document in Psychology

-(1983). Measuring individual differences in empathy: Evidence for a multidimensional approach. Journal of Personality and Social Psychology, 44(1), 113-126.

Eisenberg, N. (2002). Emphaty and its development. New York : Cambridge University Press

Eisenberg, N. \& Strayer. (1987). The Relation of empathy to prosocial and related behavior. Psychological Bulletin, 101 (1), 91-119

Erhamwilda, (2011). Model konseling sebaya untuk meningkatkan kompetensi interpersonal siswa SMK. Tidak diterbitkan. Bandung: Disertasi pada Program Studi BK UPI

Emerson, B.L., \& Hinkle, J.S. (1988). A police peer counselor uses reality therapy. Journal of Reality Therapy. Vol.8 (1), hal.2-5

Fidiyaningrum, Anis. (2006). Upaya Meningkatkan Empati Mahasiswa Dengan Memanfaatkan Media Bimbingan. Tidak diterbitkan. Semarang: Skripsi pada Program Studi BK UNS

Gladding, Samuel T. (2012). Group a counseling speciality. Person Education Inc: New Jersey

Graetz, B., \&Shute, R. (1995). Assessment of peer relationship in children with asthma. Journal of Pediatric psychology, 20, 2, hal.205-216

Goleman, D.L (1998). Kecerdasan emosional. Mendefinisikan ulang arti Kecerdasan. Jakarta : PT Gramedia Pustaka Utama

(2003). Social integency. Ilmu Baru tentang Hubungan Antar Manusia. Jakarta : PT Gramedia Pustaka Utama.

Garton \& Gringart, 2005. "The development of a scale to measure empathy in 8- and 9-year old children". Australian Journal of Education and Developmental Psychology Vol. 5, 2005, pp 17-25

Joireman, J.A., T. L Needham, \& A. Cumming. 2002. "Relationships between dimensions of attachement and empathy." North America journal of Psychology 4: 63-80

Kurnia, Rina. (2014). Efektivitas bimbingan kelompok melalui teknik role playing untuk meningkatkan kemampuan empati peserta didik. Tidak diterbitkan. Bandung: Tesis pada Program Studi BK UPI

Kusminar, Mimin. (2013). Program bimbingan pribadi sosial untuk meningkatkan empati anak melalui media permainan. Tidak diterbitkan. Bandung: Tesis pada Program Studi BK UPI.

Likert, R. (1932). A technique for the measeurement of attitudes archives of psychology, 140, 1-55.

Laursen, E.K. (2005). Tather than faxing kids - build positive peer culture. reclaiming children and youth. 14 (3). 137 - 142. (ProQuest Education Jounals). 